\title{
GENEALOGY, DIASPORA, AND DA'WAH: The Religious Role of Sheikh Ibrahim al-Hadhrami in Pattani and Java
}

Muaz Tanjung, ${ }^{1}$ Arik Dwijayanto, ${ }^{2}$ and Nabil Cheng-Kung $\operatorname{Lin}^{3}$

${ }^{1}$ UIN Sumatera Utara, Medan

${ }^{2}$ Institut Agama Islam Sunan Giri Ponorogo, Jawa Timur

${ }^{3}$ National Cheng Kung University, Taiwan

email: muaztanjunguinsu@gmail.com¹, arikdj99@gmail.com²,

ncklin55@gmail.com ${ }^{3}$

Abstract: There are several problems in the historiography of Islam Nusantara nowadays. One of them is the lack of written sources, especially during the XIV-XV centuries. It was a significant period when the early generation of preachers (Walisongo) played a significant role in spreading Islam in the archipelago. Because of the limitations of written sources, some scholars assume Walisongo as a myth. This article aims to reveal the genealogy, sanad, and religious roles of one of the early Walisongo, Shaykh Ibrahim al-Hadrami, in Pattani and Java. This study applied historical research methods. It relied on critical testing and analysis, including heuristics, verification, interpretation, and historiography. Besides, the findings showed the continuity of the genealogy and sanad of Shaykh Ibrahim al-Hadrami and his descendants. They formed a network of Ulama and da'wah centers in Pattani and Java. In Pattani, Islamic preaching centers built by Sheikh Ibrahim al-Hadrami were continued by his descendants, such as Sheikh Ahmad bin Muhammad Zain al-Fathani and Sheikh Daud al-Fathani. They developed in Kedah, Kelantan, and several areas in the Malay Peninsula. Meanwhile, in Java, the centers of Islamic da'wah built by Sheikh Ibrahim al-Hadrami were continued by his two sons, Raden Rahmat (Sunan Ampel) and Raden Ali Murtadla 
(Sunan Gresik) and their descendants. Therefore, Islam developed throughout Java.

الملخص : بعض مشاكل التاريخ الإسلامي في الأرخبيل لا تزال تطفو على السطح حتى الآن.

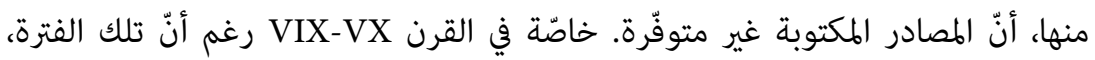

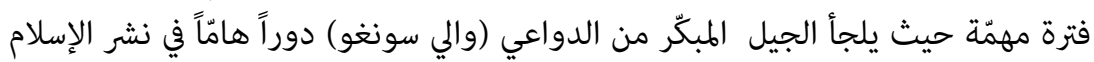

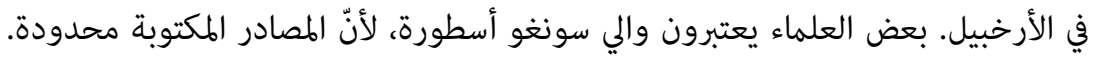

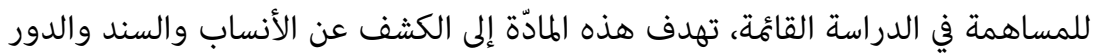

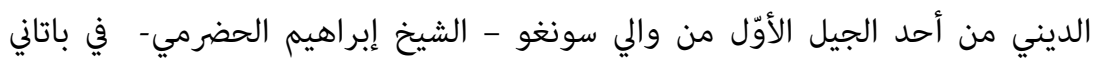

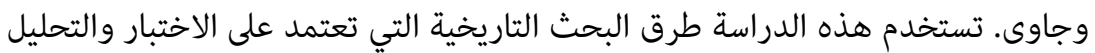

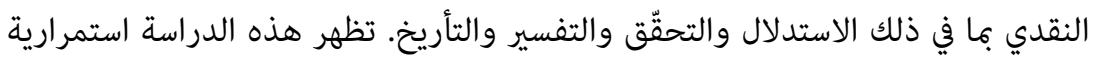

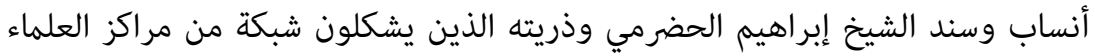

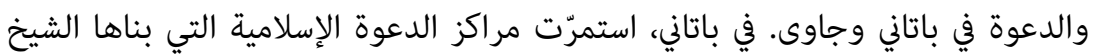

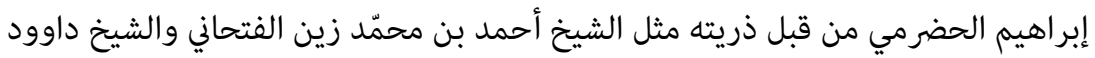

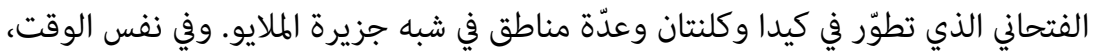

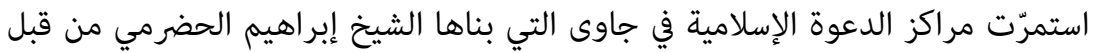

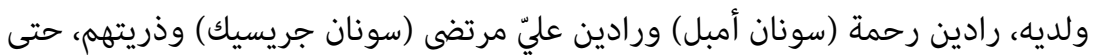
تطوّر الإسلام في جميع أنحاء جاوى. رحمة آدين

Abstrak: Beberapa permasalahan dalam historiografi Islam Nusantara sampai saat ini masih terus mengemuka, salah satunya adalah kurangnya sumber tertulis, khususnya masa abad XIV-XV. Padahal masa tersebut merupakan masa yang sangat penting dimana generasi awal para pendakwah (Walisongo) memainkan peranan signifikan dalam menyebarkan Islam di Nusantara. Keterbatasan sumber tertulis menjadikan sebagian cendekiawan menganggap Walisongo sebagai mitos. Untuk berkontribusi pada studi yang ada, artikel ini bertujuan untuk mengungkap silsilah, sanad dan peran keagamaan salah satu Walisongo generasi awal, yakni Syaikh Ibrahim al-Hadrami di Pattani dan Jawa. Penelitian ini menggunakan metode penelitian sejarah yang bertumpu pada pengujian dan analisis kritis meliputi heuristik, verifikasi, interpretasi, dan historiografi. Kajian ini menunjukkan ketersambungan silsilah dan sanad Syaikh Ibrahim al Hadrami serta keturunannya yang membentuk 
jejaring Ulama dan sentra-sentra dakwah di Pattani dan Jawa. Di Pattani, sentra-sentra dakwah Islam yang dibangun Syaikh Ibrahim al-Hadrami dilanjutkan oleh keturunannya, seperti Syaikh Ahmad bin Muhammad Zain al-Fathani and Syaikh Daud al-Fathani yang berkembang di Kedah, Kelantan dan beberapa kawasan di Semenanjung Melayu. Sedangkan di Jawa, sentrasentra dakwah Islam yang dibangun Syaikh Ibrahim al-Hadrami dilanjutkan oleh kedua putranya, Raden Rahmat (Sunan Ampel) dan Raden Ali Murtadla (Sunan Gresik) beserta keturunannya sehingga Islam berkembang diseluruh wilayah tanah Jawa.

Keywords: genealogy, sanad, da'wah, Hadrami, Java.

\section{INTRODUCTION}

Sheikh Ibrahim al-Hadrami was one of the influential scholars in the preaching of Islam in Java. He was the son of Sheikh Jumadil Kubra as well as the father of Raden Ahmad Rahmatullah or Sunan Ampel. Sheikh Ibrahim al-Hadrami, in Java better known as Ibrahim Asmarakandi, had several names including Ibrahim al-Ghazi, Syarif Auliya, Karimul Makhdum, Sayyid Ibrahim Zainul Akbar, and Zainuddin al-Akbar Ibrahim. ${ }^{1}$

Based on several Javanese historiography studies, Sheikh Ibrahim Asmarakandi was often likened to Sheikh Maulana Malik Ibrahim. It caused complications in analyzing the story of his life and his origins. Even his family's genealogy led to the denial of Sheikh Ibrahim Asmarakandi as a historical figure. The tomb and gate sites and the mosque's mihrab in the shelter of the ancient service point to the location and different eras of Maulana Malik Ibrahim tomb site. ${ }^{2}$

Based on Pattani's source, it was mentioned that Sheikh Ibrahim al-Hadhrami was born in Krisik, Pattani, before migrating to Java. The region's name was almost the same as the area in East Java,

' Robert Bertram Serjeant, The Saiyids of Hadramawt (School of Oriental and African Studies, University of London, 1957); Haji Wan Mohd Shaghir Abdullah, "Penyebaran Islam Dan Silsilah Ulama Sejagat Dunia Melayu" (Khazanah Fathaniyah, 1999).

Agus Sunyoto, Atlas Wali Songo, Pustaaka IIman \& Lesbuni PBNU, 2017: Atlas Wali Songo, vol. 1 (Buku Digital, 2017); Syed Muhammad Naquib al-Attas, Historical Fact and Fiction (Penerbit UTM Press, 2011). 
Gresik. Sheikh Ibrahim al-Hadhrami married Wan Maimunah Binti Yusuf al-Syandani in Pattani and had five children, Sheikh Wan Abdur Rahman, Wan Jamilah al-Syandaniyah, Sheikh Wan Yahya, Sheikh Wan Muhammad Yasin, and Sheikh Wan Husein. ${ }^{3}$ From his descendants in Pattani, some became Ulama, and figures spread across various regions of Pattani, Kedah, Kelantan, and elsewhere in the Malay Peninsula. Meanwhile, his descendants in Java also were scholars through his son Raden Ahmad Rahmatullah or Sunan Ampel. Sheikh Ibrahim al-Hadhrami was a significant Ulama in spreading Islam in the archipelago, Java and Pattani.

\section{LINEAGE (SANAD) OF SHEIKH IBRAHIM AL-HADHRAMI AND DA'WAH JOURNEY TO NUSANTARA}

Tracing the gait of Sheikh Ibrahim al-Hadhrami in the journey of propagation to develop Islam in the archipelago, especially in Java, could not be separated from the genealogy. It was a link of kinship or family and also lineage (sanad) of science. ${ }^{4}$ Sheikh Ibrahim alHadhrami was Sheikh Jamaluddin al-Hadrami al-Jarimi al-Yamani or Sayyid Jamaluddin Akbar. He was known in Java as Sheikh Jumadil Kubra. Grandfather Sheikh Jumadil Kubra, Ahmad al-Jarimi alYamani, or Ahmad Shah Jalal, moved to Yemen through the country of Sham. ${ }^{5}$ Sheikh Jumadil Kubra or Sheikh Jamaluddin al-Hadrami from Yemen migrated to Southeast Asia and emigrated to several regions. In Pattani, Sheikh Jumadil Kubra opened a new village called Jerim/Jaram village or in Pattani dialect called Jering village. Sheikh Jumadil Kubra was also known as the spreader of Islam in Champa (Cambodia) in the 14th and 15th centuries AD. ${ }^{6}$ In Champa, Sheikh Jumadil Kubra married Ramawati, the daughter of King Champa, Sultan Zaenal Abidin Shah. Sheikh Jumadil Kubra then migrated to Aceh and then sailed to Semarang to Mojopahit (Mojokerto). Sheikh

3 W M Shaghir Abdullah, Tarikh Fathani (Kuala Lumpur: Khazanah Fathaniyah, 1998); Andries Teeuw and David K Wyatt, "Hikayat Pattani," in Hikayat Pattani the Story of Pattani (Springer, 1970), 68-145.

4 Abdurrohman Kasdi, "The Role of Walisongo in Developing the Islam Nusantara Civilization," Addin 11, no. 1 (2017): 1-26.

5 Martin Van Bruinessen, "Studies of Sufism and the Sufi Orders in Indonesia," Die Welt Des Islams 38, no. 2 (1998): 192-219.

6 Teeuw and Wyatt, "Hikayat Pattani"; Abdullah, Tarikh Fathani. 
Jumadil Kubra had three sons. They were Sheikh Ibrahim, Sheikh Zainal Alam, and Sheikh Ali Nur Alam. ${ }^{7}$

There were various sources about Sheikh Ibrahim al-Hadhrami. According to the Malaysian scholar, Wan Mohd Shaghir Abdullah, he was born in Krisik, Pattani. Then, he migrated to Champa. He married the daughter of King Champa and had a descendant who became the spreader of Islam in Java and several other areas. Meanwhile, according to Indonesian scholar Agus Sunyoto, Sheikh Ibrahim al-Hadhrami or Ibrahim Asmarakandi grew up in Champa. Then, he married Princess Wira Bhadrawarman -who succeeded his Father Jaya Sinhawarman, in 1401 AD. From his marriage to Princess Champa, Sheikh Ibrahim al-Hadhrami was blessed with four children based on the two sources. They were Maulana Ishaq, Raden Ahmad Rahmatullah, or Sunan Ampel, Ali Murtadho or Raden Santri, and Siti Zainab. ${ }^{8}$

Based on Javanese historiography, ${ }^{9}$ it was stated that Sheikh Ibrahim al-Hadhrami or Sheikh Ibrahim Asmarakandi was born in Samarkand, Central Asia, in the second half of the 14th century. Babad Tanah Jawi mentioned his name with Makhdum Ibrahim Asmara or Maulana Ibrahim Asmara. The name followed the recitation of the Javanese tongue to al-Samarkandy, which later turned into Asmarakandi. According to Babad Cirebon, Sheikh Ibrahim Asmarakandi was Sheikh Karnen who came from Tulen country. It was assumed that the source of data from Babad Cirebon is authentic. In that case, Sheikh Ibrahim Asmarakandi is not a native of Samarkand. However, an immigrant who followed his parents moved to Samarkand. The Tulen country in question refers to the Tyulen region, a small island on the eastern edge of the Caspian Sea entering Kazakhstan, Samarkand Sea. Meanwhile, according to Babad Ngampeldenta, Sheikh Ibrahim Asmarakandi was known as Sheikh Maulana, the spreader of Islam in the Land of Champa.

7 Serjeant, The Saiyids of Hadramawt; Sunyoto, Atlas Wali Songo, Pustaaka IIman \& Lesbuni PBNU, 2017: Atlas Wali Songo.

8 Abdullah, "Penyebaran Islam Dan Silsilah Ulama Sejagat Dunia Melayu"; Sunyoto, Atlas Wali Songo, Pustaaka IIman \& Lesbuni PBNU, 2017: Atlas Wali Songo.

9 Anthony H Johns, "The Role of Structural Organisation and Myth in Javanese Historiography," The Journal of Asian Studies 24, no. 1 (1964): 91-99; D G E Hall, "Problems of Indonesian Historiography," Pacific Affairs 38, no. 3/4 (1965): 353-59; Bambang Purwanto and M Nursam, Gagalnya Historiografi Indonesiasentris (Ombak, 2006). 
Sheikh Ibrahim Asmarakandi was narrated successfully to Islamize King Champa and taken to be son in law. From his wife, who was a princess of King Champa, Sheikh Ibrahim Asmarakandi had a son, Raden Rahmat. In Babad Risakipun Majapahit and Serat Walisanga Babadipun Para Wali, Sheikh Ibrahim Asmarakandi was asked to come to Champa. He was asked to preach and succeed in Islamizing the king marrying the king's daughter. In the script Negarakretabhumi Sarga IV, Sheikh Ibrahim Asmarakandi was called as Maulana Ibrahim Akbar who holds Sheikh Jatiswara. As in the Negarakretabhumi text, Maulana Ibrahim Akbar was referred to as the father of Ali Musada (Ali Murtadlo) and Ali Rahmatullah or Sunan Ampel. ${ }^{10}$

According to the chronological order of time, Sheikh Ibrahim Asmarakandi or Sheikh Ibrahim al-Hadhrami was expected to come to Java around $1362 \mathrm{~J} / 1440 \mathrm{AD}$. His two sons, nephew, and several relatives faced King Majapahit. He married his wife's sister, namely Dewi Darawati. Before Java, Sheikh Ibrahim al-Hadhrami stopped in Palembang earlier to introduce Islam to the Duke of Palembang, Arya Damar. He successfully Islamized the Duke of Palembang, Arya Damar, who was replaced by Arya Abdillah and his family. Later, he, his son and nephew, continued their journey to Java Island. The group landed on the east side of Tuban, called Gisik (now Gisikharjo Village, Palang Subdistrict, Tuban Regency). The landing of Sheikh Ibrahim al-Hadhrami or Sheikh Ibrahim Asmarakandi in Gisik could be understood as an Islamic preacher prudence strategy. Bandar Tuban is the central port city of Majapahit. Sheikh Ibrahim Asmarakandi and his entourage lived on the east of the port of Tuban, namely Gisik, to preach Islam to the people around there. ${ }^{11}$

A handwritten book in Java pesantren known as Usul Nem Bis was a book of six books with six bismilllahirahmanirahim written in the name of Sheikh Ibrahim Asmarakandi. It meant that while preaching Islam, Sheikh Ibrahim Asmarakandi also compiled a book.

${ }^{10}$ Johannes Jacobus Ras, "The Genesis of the Babad Tanah Jawi: Origin and Function of the Javanese Court Chronicle," Bijdragen Tot de Taal-, Land-En Volkenkunde, no. 2/3de Afl (1987): 343-56; M C Ricklefs, "The Evolution of Babad Tanah Jawi Texts: In Response to Day," Bijdragen Tot de Taal-, Land-En Volkenkunde, no. 4de Afl (1979): 443-54.

${ }^{11}$ Douwe Adolf Rinkes, Nine Saints of Java (Malaysian Sociological Research Institute, 1996); Kasdi, "The Role of Walisongo in Developing the Islam Nusantara Civilization." 
According to the oral story, Sheikh Ibrahim Asmarakandi's preaching in Gisik was not so long. Before he came to the capital of Majapahit, Sheikh Ibrahim Asmarakandi reportedly died and was buried in Gisik not far from the beach. Because he was considered the first Islamic spreader in Gisik and the Father of Sunan Ampel, his tomb was sacred by society and known as Sunan Gisik. It was narrated that after the death of Sheikh Ibrahim Asmarakandi, his sons (Ali Murtadho and Ali Rahmatullah) with his nephew, Raden Burereh (Abu Hurairah), and some relatives from Champa continued their journey to the capital of Majapahit. They wanted to meet their aunt, Dewi Darawati, who married Majapahit King. The journey to the capital of Majapahit was then made by following the road from the Port of Tuban to kutaraja Majapahit. $^{12}$

Meanwhile, Sheikh Ibrahim Asmarakandi or Sheikh Ibrahim al-Hadhrami had Sheikh Ahmad Syah Zainul Alam and Maulana Malik Ibrahim. He had a son, Abdur Rahman al-Rumi. From this genealogy, it could be seen that Maulana Malik Ibrahim was the son of Sheikh Zainul Alam, the brother of Sheikh Ibrahim al-Hadhrami. The genealogy version of Pattani provided information that Sheikh Ibrahim al-Hadhrami or Ibrahim Asmarakandi and Maulana Malik Ibrahim were different people though still in very close kinship ties. According to the statement, there are differences of opinion in Hamid Algadri. Sunan Ampel (Raden Rahmat) was the son of Maulana Malik Ibrahim. In addition, there was another opinion. It stated that Maulana Malik Ibrahim was the brother of Sheikh Ibrahim al-Hadhrami or Ibrahim Asmarakandi, as written by Ibhar in his book Wali Songo. According to him, Maulana Malik Ibrahim was the eldest son of Sheikh Jumadil Kubra with Princess Linang Cahaya, who was the younger sister of Siti Wan Kembang. In his view, when in Champa, Sheikh Jumadil Kubra married Ramawati. She was the daughter of Sultan Zainal Abidin and Permaisuri Siti Zubaidah (Dewi Sudaksina), who gave birth to Ibrahim Asmarakandi. ${ }^{13}$

${ }^{12}$ Putut Handoko, "A Historical of Sunan Ampel (Raden Rahmad) and Sunan Boto Putih (Lanang Dhangiran) Surabaya," Voicing Peace" Harmony Through Multidisiplinary Study", 2017, 1-5; Sunyoto, Atlas Wali Songo, Pustaaka IIman \& Lesbuni PBNU, 2017: Atlas Wali Songo.

${ }^{13}$ Hamid Algadri, Dutch Policy against Islam and Indonesians of Arab Descent in Indonesia (Lp3es, 1994); James J Fox, "Nine Saints of Java” (JSTOR, 2001). 
Maulana Malik Ibrahim was the oldest Wali Songo with Maulana Maghribi or Sheikh Maghribi, Sunan Gresik. According to the source of history, there was information that he came from Persia. Another source stated that he was of Arab descent in Kashan. Meanwhile, other opinions stated that he was from Gujarat, India. Thomas S. Raffles, in History of Java, mentioned that Maulana Malik Ibrahim was an Arab descendant. However, his arrival to Java was as the head of a group of Islamic preachers around $1397 \mathrm{AD}$. Also, he was the chairman of the entourage with Raja Cermin and his sons to Islamize King Majapahit. In addition to Raja Cermin, some Maulana Malik Ibrahim's cousins participated in Sayyid Ja'far, Sayyid Qasim, and Sayyid Khairat. However, most of them who followed the group returned to Negeri Cermin. As the missionary journey of Sheikh Jamaluddin al-Kubra, Sheikh Ibrahim al-Hadhrami, and Maulana Malik Ibrahim, when going to preach to Java, he began to depart from Pattani. ${ }^{14}$

Concerning Negeri, Cermin, according to Raffles's opinion, was located in the Hindustan area. However, almost all writers from Kelantan, such as Abdul Rahman Al-Ahmadi, Abdullah bin Muhammad (Nakula), and others, argued that Negeri Cermin was located in Kelantan or Pattani. Therefore, Sheikh Ahmad al-Fathani, namely Pattani region as Negeri Cermin (the Land of Mirror of Mecca). Nevertheless, there was also the opinion that Negeri Cermin was located in Brunei. This opinion was written by Haji Awang Mohd. Jamil al-Sufri in his Tarsilah Brunei: The Early History and Development of Islam. ${ }^{15}$

After being settled in Gresik, East Java, Maulana Malik Ibrahim built a mosque and boarding school. He spread Islam until his death at 12 Rabiulawal 882 H/1419 AD, buried in Wetan Gapura, Gresik, East Java. ${ }^{16}$ Meanwhile, the third brother of Sheikh Ibrahim al-Hadhrami was Sheikh Ali Nurul Alam. Some opinions stated that Sheikh Ali Nur Alam died in Champa in 1467 AD. His body was buried in Kampung Garak Ruwain (Binjal Lima or Binje Limo). Another opinion stated

${ }^{14}$ Thomas Stamford Raffles, The History of Java: Volume I, vol. 1 (BoD-Books on Demand, 2018); Serjeant, The Saiyids of Hadramawt.

${ }^{15}$ Mohd Jamil Al-Sufri, Tarsilah Brunei: The Early History of Brunei up to 1432 $A D$, vol. 1 (Brunei History Centre, Ministry of Culture, Youth and Sports, 2000).

${ }^{16}$ W M Shaghir Abdullah, "Wawasan Pemikiran Islam Ulama Asia Tenggara, Jil. 1," Kuala Lumpur: Persatuan Pengkajian Khazanah Klasik Nusantara \& Khazanah Fathaniyah, 2000. 
that Sheikh Nurul Alam once settled in Egypt. Based on the study of Wan Mohd Shaghir Abdullah, the children of Sheikh Ali Nur Alam were:

1. Wan Abdullah or Maulana Sultan Mahmud (Sultan Champa).

2. Wan Husein Sanawi.

3. Wan Demali.

4. Wan Hasan.

5. Wan Jamal.

6. Wan Biru.

7. Wan Senik.

8. Sheikh Wan Muhammad Shalih al-Laqihi.

9. Maulana Abu Ishaq. ${ }^{17}$

According to some historical sources, it was stated that Sultan Umdatullah or Wan Abdullah or Maulana Sultan Mahmud had three sons, namely:

1. Sharif Hidayatullah or Sunan Gunung Jati.

2. Sultan Babullah, Sultan of Ternate (1570-1583 AD).

3. Maulana Abdul Muzaffar Ahmad.

Syarif Hidayatullah or Sunan Gunung Jati bin Sultan Umdatullah bin Sheikh Ali Nurul Alam had some children, namely:

1. Maulana Sultan Hasanuddin, Sultan of Banten I or Sultan Habibullah Umar Imaduddin or known as Pangeran Jaya Kelana, died 1059H or 1649 AD.

2. Muhammad Hashim his grave on Mount Jati.

3. Umdatuddin Husein his grave adjacent to Mount Jati.

Maulana Sultan Hasanuddin bin Sunan Gunung Jati bin Sheikh Ali Nur Alam had two children. The first was Maulana Sultan Yusuf (Sultan Banten II), who died in Cirebon in 1070H/1659 AD. The second was Maulana Abdul Aziz, who died in 1061 H /1650 AD in Cirebon. The son of Maulana Sultan Joseph was Sultan Muhammad. Son of Sultan Muhammad was Sultan Abdul Mafakhir and the son of Sultan Abdul Mafakhir was Sultan Abdul Maali Ahmad. Besides, the

${ }^{17}$ Al-Sufri, Tarsilah Brunei: The Early History of Brunei up to 1432 AD; Abdullah, Tarikh Fathani; Teeuw and Wyatt, "Hikayat Pattani." 
son of Sultan Abul Maali Ahmad was Abdul Fattah or Sultan Ageng Tirtayasa. $^{18}$

Genealogically, Sheikh Ibrahim al-Hadrami, Sheikh Ali Nurul Alam had a close relationship with the scholars who came from Banten. The majority were descendants of Sheikh Ali Nurul Alam. Sheikh Nawawi al-Bantani (Imam Nawawi al-Tsani) was the 14th descendant of Sheikh Ali Nurul Alam. Another Banten cleric, Sheikh Abdul Karim bin Bukhari, was the 13th descendant. ${ }^{19}$ So, one of the ulama of Sunan Gunung Jati's descendants was Kiai Haji Muhammad Khalil al-Maduri or popularly known as Kiai Khalil Bangkalan. The scholars who gave birth to prominent figures in Indonesia included Kiai Haji Hasyim Asy'ari, the founder of Nahdlatul Ulama. ${ }^{20}$ Furthermore, a scholar of Sunan Gunung Jati descent in the early 20th period, who taught at the Grand Mosque was Sheikh Muhammad Ahyad, who had descendants as follows:

1. Sheikh Muhammad Ahyad bin

2. Raden Angka Wijaya/Raden Jaka or Haji Muhammad Idris bin

3. Tubagus Jaya Peraja or Haji Abu Bakar bin

4. Tubagus Mustafa al-Bakri bin

5. Tubagus Abdul Qadir bin

6. Tubagus Lanang bin

7. Tubagus Antip bin

8. Tubagus Jaya bin

9. Tubagus Sa'ad bin

10. Pangeran Adung bin

11. Pangeran Suma Kusuma Ningrat bin

12. Pangeran Yuda Ningrat bin

13. Pangeran Bayum bin

14. Pangeran Gandi or Pangeran Gazi bin

15. Pangeran Wangsa Pati bin

16. Pangeran Senapati bin

17. Pangeran Aria Kesumah bin

${ }^{18}$ Dinar Boontharm, "The Sultanate of Banten AD 1750-1808: A Social and Cultural History" (University of Hull, 2003).

${ }^{19}$ Mohammad Noviani Ardi and Fatimah Abdullah, "The History of Islam in the Malay Archipelago: An Analytical Study of Abdullah Bin Nuh's Works," 2018.

${ }^{20}$ Arik Dwijayanto and Yusmicha Ulya Afif, "A Religious State (A Study of Hasyim Asyari and Muhammad Iqbal's Thought on the Relation of Religion, State and Nationalism)," JUSPI (Jurnal Sejarah Peradaban Islam) 3, no. 2 (2020): 226-35. 
18. Pangeran Wangsa Pati

19. Pangeran Dipati Buana bin

20. Pangeran Pajajaran bin

21. Ratu Galuh bin

22. Sultan Maulana Yusuf bin

23. Sultan Maulana Hasanuddin bin

24. Sultan Maulana Makhdum Jati (Sunan Gunung Jati) ${ }^{21}$

Descendants of Sheikh Ali Nurul Alam through his great-grandson Muhammad Hashim bin Sunan Gunung Jati bin Umdatuddin bin Ali Nurul Alam had eight children:

1. Ahmad.

2. Abu Bakr.

3. Hashim.

4. Alwi.

5. Abdus Salam.

6. Mas Dewi.

7. Puteri Aminah.

8. Mas Dewi Puteri Saidah. ${ }^{22}$

Descendants of Sheikh Ali Nurul Alam through his grandson Umdatuddin Husein bin Sunan Gunung Jati bin Umdatuddin bin Sayyid Ali Nurul Alam had two children:

1. Syarifah Tolkah Ratu Mindo.

2. Syarifah Alawiyah Ratu Demang. ${ }^{23}$

According to Wan Mohd Shaghir Abdullah, Islamic propagators in the Hadrami family of Sheikh Ali Nurul Alam, Sheikh Zainal Alam, and Sheikh Ibrahim Asmarakandi were from Hadhramaut descendants of 'al-Aidrus.' They wandered Islam throughout the archipelago in Cambodia, Java, Bugis, Borneo, Sumbawa, Aceh, and other places..$^{24}$ It

${ }^{21}$ Claude Guillot, Hasan Muarif Ambary, and Jacques Dumarçay, The Sultanate of Banten (Gramedia Book Pub. Division, 1990).

${ }^{22}$ Boontharm, "The Sultanate of Banten AD 1750-1808: A Social and Cultural History."

${ }^{23}$ Abdullah, "Penyebaran Islam Dan Silsilah Ulama Sejagat Dunia Melayu."

${ }^{24}$ Francis R Bradley, "Moral Order in a Time of Damnation: The Hikayat Pattani in Historical Context," Journal of Southeast Asian Studies 40, no. 2 (2009): 267-93; Numan Hayimasae, "Jaringan'Ulama Pattani Dengan Utara Semenanjung Tanah Melayu Abad Ke-18 Dan Ke-19," Malaysia Dari Segi Sejarah, Bil. 37, 2009, Ms. 18 30., 2009. 
was shown that the spread of Islam in Southeast Asia, especially in the Land of Java and Malay, began from Sheikh Jamaluddin al-Hadrami. Then, it was followed by his son, Sheikh Ibrahim al-Hadhrami, and his descendants. Here is the complete lineage of Sheikh Ibrahim alHadhrami: ${ }^{25}$

1. Ibrahim al-Hadhrami or Ibrahim Asmarakandi bin

2. Jamaluddin Husein or Jumadil Kubra bin

3. Ahmad Shah Jalal bin

4. Abdullah or Amir Abdullah Khan bin

5. Abdul Malik bin

6. Alawi bin

7. Muhammad or Muhammad Sahib Marbat bin

8. Ali or Ali Khali Qasam bin

9. Alawi bin

10. Muhammad bin

11. Alawi bin

12. Abdullah or Ubaidillah bin

13. Ahmad al-Muhajir or Ahmad al-Jarimi al-Yamani bin

14. Isa al-Naqib bin

15. Muhammad al-Faqih or Muhammad Naqib bin

16. Ali al-Uraidli bin

17. Ja'far al Sadiq bin

18. Muhammad al Baqir

19. Ali Zainal Abidin bin

20. Husayn bin

21. Sayyidina Ali bin Abi Thalib

\section{DA'WAH OF SHEIKH IBRAHIM AL-HADHRAMI AND HIS DESCENDANTS IN PATTANI}

Wan Mohd Shagir Abdullah explained the descendants of Sheikh Ibrahim al Hadrami with his first wife, Wan Maimunah bint Yusuf al-Syandani. Sheik Wan Ibrahim's first son, who had a daughter, Wan Zainab, later married Sheikh Wan Senik al-Karisiqi. The Father of Sheikh Wan Senik al-Karisiqi was Sheikh Wan Ali bin Mansur, and his mother was Wan Jamilah al-Syandaniyah. She was the second son of Sheikh Ibrahim al-Hadhrami. So between Sheikh Wan Senik

${ }^{25}$ Abdullah, "Penyebaran Islam Dan Silsilah Ulama Sejagat Dunia Melayu"; Sunyoto, Atlas Wali Songo, Pustaaka IIman \& Lesbuni PBNU, 2017: Atlas Wali Songo. 
al-Karisiqi with Wan Zainab were classified as a cousin. From the marriage, they had two sons, Sheikh Wan Idris al-Karisiqi and Sheikh Wan Husein al-Karisiqi. Based on Sheikh Muhammad Nur al-Fathani's handwritten genealogy as Wan Mohd Shagir Abdullah quoted, Sheikh Wan Senik, who earned titles as Tok Wan Dahit, married Tok Wan Ti. He was the son of Tok Wan Abu Bakar. The marriage blessed with a child, Wan Tih. Therefore, Sheikh Wan Senik al-Karisiqi married twice. The first was with his cousin of Sheikh Ibrahim al-Hadhrami, and the second was with the descendant of Sheikh Faqih Ali. The second son of Sheikh Wan Senik al-Karisiqi from the first wife, Sheikh Wan Husein al-Karisiqi had two children who became the great scholars of Pattani. They were Sheikh Wan Ahmad as-Samlawi and Sheikh Wan Musa al-Samlawi al-Fathani. Sheikh Wan Musa al-Samlawi al-Fathani continued the boarding school tradition in Samela. It was the oldest Islamic boarding school (pesantren) in Fathani Darus Salam based on oral sources. ${ }^{26}$

Meanwhile, Sheikh Wan Idris al-Karisiqi al-Fathani had a son, namely Sheikh Wan Abdullah al-Fathani. Sheikh Wan Abdullah alFathani was married to Wan Fatima and had six children: Bahjatuddin Sheikh Wan Daud, Sheikh Wan Abdul Qadir, Sheikh Wan Abdur Rashid, Sheikh Wan Idris, Sheikh Wan Umar, and sixth daughter, unnamed. As for Sheikh Wan Daud bin Abdullah al-Fathani in the source, Wan Mohd Shaghir had no descendant. Despite not having descendants, Sheikh Wan Daud bin Abdullah al-Fathani had many disciples. While his younger brother, Sheikh Wan Abdul Qadir, had a son, Sheikh Wan Muhammad Shalih. Sheikh Abdur Rahman alFathani had two children who became great scholars in Mecca. The first child was Sheikh Wan Muhammad al-Fathani, the musahhih (books corrector) in Mecca. It was also a part of the Ottoman Turks Empire at that time, after his teacher Sheikh Ahmad bin Muhammad Zain al-Fathani. The second son of Sheikh Abdul Qadir bin Abdur Rahman al-Fathani was Sheikh Wan Daud al-Fathani. He was a great scholar in Mecca who taught in Darul Ulum and at the Grand Mosque (Masjid al-Haram). ${ }^{27}$

${ }^{26}$ Teeuw and Wyatt, "Hikayat Pattani”; Abdullah, Tarikh Fathani.

${ }^{27}$ Wan Mohd Shaghir'Abdullah, "Manhalush Shafi Syekh Daud Al-Fathani" (Kuala Lumpur: Khazanah Fathaniyah, 1992); Wan Mohd Shaghir Abdullah, "Syeikh 
The descendants of Sheikh Ibrahim al-Hadhrami from the second son of Wan Jamilah Syandaniyah sent some great scholars through the path of Sheikh Wan Muhammad bin Sheikh Muhammad Dahan bin Sheikh Shamsuddin bin Sheikh Jafar. Wan Jamilah's husband was Sheikh Jafar bin Sheikh Wan Husein bin Sheikh Ali. Sheikh Wan Muhammad Dahan al-Fathani had three children who also become scholars of Sheikh Wan Muhammad al-Fathani. They generated Bani Tuan Minal, Sheikh Wan Abdul Karim, who generated Bani Tok Raja Haji Jambu. Sheikh Wan Abdul Lathif al-Fathani who generated Bani Tok Duku and Telok Manok. In summary, the descendants were as follows:

1. Sheikh Muhammad Zainal Abidin al-Fathani bin Muhammad bin Muhammad Dahan bin Syamsuddin bin Jafar bin Wan Husayn bin Ali. The lineage was grouped under Bani Minal. The Ulama of Bani Tuan Minal belonged to the famous clerics in the Malay Peninsula because of his widespread works such as Aqidatun Najin, Kasyful Litsam, and Kasyful Ghaibiyah.

2. Tuan Guru Haji Idris bin Sheikh Wan Abdul Karim bin Wan Muhammad Dahan bin Syamsuddin bin Jafar bin Wan Husein bin Ali. The descendant was grouped into Bani Tok Raja Haji Jambu.

3. Sheikh Wan Abdul Lathif bin Muhammad Dahan bin Syamsuddin bin Jafar bin Husay ibn Sheikh Ali. The descendant was grouped into Bani Tok Duku and Telok Manok. ${ }^{28}$

While Sheikh Zainal Abidin bin Muhammad al-Fathani had several children, they are:

1. Daud al-Fathani

2. Abdul Qadir al-Fathani

3. Muhammad Shalih al-Fathani, the author of Siraj al-Qari.

4. Umar al-Fathani, Mursyid Tariqat Syatariyah

5. Hassan al-Fathani

6. Fatmah al-Fathani. ${ }^{29}$

Ahmad Al-Fathani: Pemikir Agung Melayu Dan Islam” (Persatuan Pengkajian Khazanah Klasik Nusantara; Khazanah Fathaniyah, 2005).

${ }_{28}$ Abdullah, "Penyebaran Islam Dan Silsilah Ulama Sejagat Dunia Melayu"; Abdullah, Tarikh Fathani.

${ }^{29}$ Ghafirah Idris, "Shaykh Zayn Al-Abidin Bin Muhammad Al-Fatanis Discourse on Eschatology" (Kuala Lumpur: Kulliyah of Islamic Revealed Knowledge and Human Science ..., 2012). 
The second son of Sheikh Zainal Abidin, Abdul Qadir al-Fathani, was married twice. The first marriage in Kelantan had two children while the second marriage in Muar, Johor with Shafiyah had seven children. In the middle of 1998, the second marriage of Abdul Qadir al-Fathani in Johor when following Sheikh Ahmad bin Muhammad Zain al-Fathani visited the Kingdom of Johor. The Sultan then offered Sheikh Ahmad al-Fathani to stay in Johor to be sworn as Mufti, but he refused. ${ }^{30}$ From the first marriage, Abdul Qadir al-Fathani had the first child known as Haji Sulong. He was the Father of the Pattani Revolution. He struggled to release Pattani from the occupation of the Siam Kingdom. The second son of Abdul Qadir al-Fathani was Abdur Rahim bin Abdul Qadir. Also, from the second marriage, Abd al-Qadir al-Fathani had seven children. They were:

1. Zainab Binti Abdul Qadir al-Fathani

2. Maryam Binti Abdul Qadir al-Fathani

3. Abdullah Bin Abdul Qadir al-Fathani

4. Mahmud Nur Bin Abdul Qadir al-Fathani

5. Khadijah Binti Abdul Qadir al-Fathani

6. Mahmud Bin Abdul Qadir al-Fathani

7. Fatimah Binti Abdul Qadir al-Fathani. ${ }^{31}$

As mentioned, the siblings of Sheikh Muhammad al-Fathani were Sheikh Abdul Karim and Sheikh Wan Abdul Lathif. Sheikh Wan Abdul Karim bin Muhammad al-Fathani had the son, namely Wan Idris al-Fathani, known among the Malay Pattani community as a cleric with a title with Tok Raja Haji, for establishing Pondok Tok Raja Haji, Jambu. In addition, to teach in the Islamic boarding school or pesantren, Sheikh Wan Idris al-Fathani also produced several works. He married Hajah Wan Mah, a cousin of Sheikh Ismail bin Sheikh Abdul Qadir Daya. In the second marriage with Wan Maryam, he had ten children. The third marriage with Hajah Wan Aisyah bint

${ }^{30}$ Hasanudin Daud, "Syeikh Ahmad Bin Muhammad Zain Al-Pattani: Peranan Dan Sumbangannya Dalam Perkembangan Ilmu Keagamaan/Hasanudin Bin Daud" (University of Malaya, 2003).

${ }^{31}$ Mohd Khairul Nizam, Mahmud Ahmad, and Nurul Jannah, "Syeikh Abdul Qadir Bin Abdur Rahim Al-Fathani Bukit Bayas (1864) Towards Hadith Works and Writings of Fiqh Muamalat Al-Maliyyah: An Introduction of The Malay Jawi Manuscript Entitled: Risalah Fi Bayani Hukmi Bai'i War Riba," International Journal of Nusantara Islam 2, no. 1 (2014): 32-41. 
Sheikh Abdul Qadir al-Fathani (Tok Bendang Daya II). He had two sons through this third marriage, Haji Wan Abdul Qadir and Haji Abdul Hamid. One of the daughters of Tuan Guru Wan Idris alFathani married Master Haji Wan Daud bin Haji Wan Yusuf bin Haji Awan Tarat al-Fathani. He was one of his students who also produced several works. ${ }^{32}$

The next son of Sheikh Ibrahim al-Hadhrami, namely Sheikh Wan Muhammad Yasin, generated Sheikh Muhammad Faqih bin Muhammad Shamsuddin bin Sheikh Wan Abdul Lathif bin Wan Jamaluddin bin Sheikh Wan Idris (1266 H/1849 AD-1329 H/1911 AD). Sheikh Wan Idris was known as Sheikh Jarum/Jerum (referring to a residence in the village of Jarum/Jerum). There were many descendants of Sheikh Jarum who became scholars and community leaders in Kedah, Malaysia, and also in Pattani. Sheikh Jarum's son, Haji Abdur Rahman (d. 1954 AD), and his descendants lived in Kampung Kloung, Bangkok, Thailand. There were some grandchildren of Sheikh Idris al-Jarumi from the descendants of Haji Abdur Rahman who became scholars and community leaders. They were:

1. Tuan Guru Haji Idris bin Haji Abdur Rahman, founder of Pondok Mengkudu, Alor Setar, Kedah.

2. Haji Guru Haji Husein bin Haji Abdur Rahman, Imam of Zahir Mosque, Alor Setar, Kedah.

3. Haji Abdul Hamid bin Haji Abdur Rahman, Teacher at Maktab Mahmud, Alor Setar Kedah and also as Imam Masjid al-Irfan, Derga.

4. Dato Sheikh Tajuddin bin Haji Abdur Rahman, was a member of Majlis Fatwa Religion Islam Kedah, also Member of Majlis Fatwa Kebangsaan. He also managed the Nahdhatul Hasanah Secondary School in Melele, Jitra, Kedah. ${ }^{33}$

Some descents of Sheikh Idris Jarum also became scholars and community leaders, such as Tuan Guru Haji Abdullah Sarah, one of the pesantren teachers respected by the community. That pesantren is located in Bendang Badang, the village of Sheikh Idris al-Jarumi Islam."

${ }^{32}$ Shaghir Abdullah, "Syeikh Ahmad Al-Fathani: Pemikir Agung Melayu Dan

${ }^{33}$ Ahmad Sharifuddin Mustapha et al., "Islamic Scholars in Malay Archipelago: Sheikh Daud Al-Fatani (1769-1847M) Contribution's in Fiqh Al-Shafie," Journal of Social Transformation and Regional Development 2, no. 3 (2020): 92-100. 
was born. In addition, the great-grandson of Sheikh Jarum was Ustadz Fadhil bin Haji Mohd Noor, an academician who taught at Universiti Teknologi Malaysia. ${ }^{34}$

\section{DA'WAH OF SHEIKH IBRAHIM AL-HADHRAMI AND HIS DESCENDANTS IN JAVA}

The descendants of Sheikh Ibrahim al-Hadhrami based on the version of Pattani as cited by Wan Mohd Shaghir Abdullah from various documents, notes, books, and interviews carried out explained that the marriage of Sheikh Ibrahim al-Hadhrami with the daughter of King Champa blessed with three children who became the great Ulama in the Land of Java was Maulana Ishaq. His full name was Maulana Imam Ishaq Makhdum or Makhdum Ishaq who was assigned to spread Islam in Blambangan. Maulana Ishaq married the Dewi Sekardadu, the daughter of King Blambangan. From that marriage, they were blessed with three children. They are:

1. Raden Paku or Imam Muhammad Ainul Yaqin (Sunan Giri).

2. Prince Darmakusuma.

3. Prince Ali Kusumowiro who had a son namely Fadhullah, Sunan Prapen. ${ }^{35}$

Maulana Ishaq left Java and migrated to Pasai and Melaka. Some people stated that in the journey of Da'wa Maulana Ishaq's death in Pasai, there was also information about his death in Melaka. Other sources claimed that he died in Wajok, South Sulawesi. Another son of Sheikh Ibrahim al-Hadhrami, Raden Ahmad Rahmatullah or Sunan Ampel, was born in Champa (Cambodia). According to the book of Shamsuzh Zhahirah by al-Sayyid al-Syarif bin Abdur Rahman bin Muhammad ibn Husein al-Masyhur, Raden Rahmatullah (Sunan Ampel) arrived in Java in $751 \mathrm{H} / 1351 \mathrm{AD}$ at the age of 20 years old. It meant that he was born in $731 \mathrm{AH} / 1330 \mathrm{AD}$ before Raden Rahmatullah (Sunan Ampel) came to Palembang, and became a guest of Arya Damar who was Islamized and renamely as Abdullah. In Java, Raden Rahmatullah then Islamized Jaya Wishnu, who was

${ }^{34}$ Ardi and Abdullah, "The History of Islam in the Malay Archipelago: An Analytical Study of Abdullah Bin Nuh's Works"; Abdullah, "Wawasan Pemikiran Islam Ulama Asia Tenggara, Jil. 1."

${ }^{35}$ Sunyoto, Atlas Wali Songo, Pustaaka IIman \& Lesbuni PBNU, 2017: Atlas Wali Songo; Abdullah, "Penyebaran Islam Dan Silsilah Ulama Sejagat Dunia Melayu." 
later renamed as Raden Fattah. In addition, to spread Islam in Java, Raden Rahmatullah also visited his relatives to receive news of the death of Maulana Malik Ibrahim a year earlier (1419 AD). Maulana Malik Ibrahim was the son of Sheikh Barakat Zainul Alam, the brother of Sheikh Ibrahim al-Hadhrami. Several years after settling in Tuban, Sayyid Ibrahim al-Hadhrami died and was buried in Nggesik, Tuban, East Java, about 1424 AD. Raden Ahmad Rahmatullah then established a boarding school in Ampel, Surabaya, known as Sunan Ampel. ${ }^{36}$

Based on the handwritten lineage of Sayyid Alwi bin Thahir alHaddad, which K.H.R. Abdullah bin Nuh cited, he mentioned that Sunan Ampel died in 940 H (1533 AD). Noted the year of birth 731 $\mathrm{H} / 1330 \mathrm{M}$ until the year $940 \mathrm{H} / 1533 \mathrm{M}$, Sunan Ampel died at about 209 years old. The death of Sunan Ampel had several differences. Based on the book of Panitia Haul Agung Sunan Ampel, he died in 1467 AD. According to Ibhar in the book Wali Songo, Sunan Ampel died in 1481 AD. According to the handwriting of Sayyid Alwi bin Thahir al-Haddad, which mentioned that the death of Sunan Ampel was in $940 \mathrm{H} / 1533 \mathrm{AD}$ with consideration of Sayyid Alwi recorded it with the year of migration (Hijriyah). In the past, all the records in the history of Islam in the archipelago were recorded with the year of Hijriyah. It was not by the year of Christ (Masehi - Anno Domini). The difference in determining the year of the death of Sunan Ampel most likely was due to errors in calculating from the record written with the year of Hijriyah. ${ }^{37}$

Sunan Ampel had many descendants. However, the lineage of his sons also had differences of opinion. Raden Ahmad Rahmatullah or Sunan Ampel's first wife, Nyai Ageng Manila, had another name Rohana, the daughter Aryo Tejo, Temenggung Majapahit. ${ }^{38}$ According to the first source, from a marriage with Nyai Ageng Manila, Sunan Ampel had some children as follows:

1. Siti Sariah.

2. Siti Mutmainnah.

${ }^{36}$ Fox, "Nine Saints of Java"; Kasdi, "The Role of Walisongo in Developing the Islam Nusantara Civilization."

${ }^{37}$ Handoko, "A Historical of Sunan Ampel (Raden Rahmad) and Sunan Boto Putih (Lanang Dhangiran) Surabaya."

${ }^{38}$ Sunyoto, Atlas Wali Songo, Pustaaka IIman \& Lesbuni PBNU, 2017: Atlas Wali Songo; Abdullah, "Penyebaran Islam Dan Silsilah Ulama Sejagat Dunia Melayu." 
3. Siti Hafsah.

4. Raden Maulana Makhdum Ibrahim or Sunan Bonang.

5. Raden Qasim.

Raden Ahmad Rahmatullah/Sunan Ampel's second wife, Dewi Karimah, had two children:

1. Dewi Murtasiyah married Sunan Giri.

2. Dewi Murtasimah with Raden Fatah.

Raden Ahmad Rahmatullah/Sunan Ampel's third wife, Nyai Ageng Bela, had two children:

1. Hasyim Sahibu Drajat or Sunan Drajat.

2. Mutmainnah.

Raden Ahmad Rahmatullah/Sunan Ampel's fourth wife, had four children:

1. Murtasiyah.

2. Asyiqah.

3. Alawiyah, married Syarif Hidayatullah/Sunan Gunung Jati.

4. Maulana Ahmad Hisamuddin or Sunan Lamongan, died 1014 AH / $1605 \mathrm{AD}$

In addition to those mentioned in the genealogy, the son of Raden Ahmad Rahmatullah/Sunan Ampel from his other wives:

1. Maulana Zainal Abidin or Sunan Demak became Qadi in the reign of Sultan Raden Fatah (brother-in-law). His grave was in Demak.

2. Ja' far Sadiq or Sunan Kudus, died in Kudus, in 1012 AH/1603 AD

3. Maulana Abdul Jalil Raden Asmoro, died in Japara in 1022 H/1613 $\mathrm{AD}$

Raden Rahmat (Sunan Ampel) bin Ibrahim al-Samarqandi blessed with a son namely Syarifah Syafiah gave birth a child namely Aisyah who married to Abdur Rahman (Jaka Tingkir) and had son Abdul Halim (Pangeran Benawa Surabaya). Abdul Halim (Pangeran Benawa Surabaya) had a son namely Abdur Rahman (Pangeran Sambodikdo). Abdur Rahman (Pangeran Sambodikdo) had a son Kyai Jumali. Kyai Jumali had a son namely Kyai Bisriyah. Kyai Bisriyah's son was Kyai Arfiyah. Kyai Arfiyah blessed with a child namely Nyai Salimin Dam. Nyai Salimin Dams had a child namely Kyai Idris Dam. Onwards, Kyai Idris Dam blessed with son of Kyai Abdul Halim Gelumpit. Kyai 
Abdul Halim Gelumpit blessed with two children, a woman namely Nyai Marfu'ah who married with Kyai Abdul Jalal bin Carik Pacitan bin Kyai Karang Jambo and blessed with the son namely Kyai Haji Ahmad Baidhawi Dam. Kyai Abdul Halim Gelumpit's son whose man was Abdur Rahim traveled to Singapore and the son of Abdur Rahim namely Haji Abdul Hafiz. After several years studying in Mecca then wandered to Midai Island and opened coconut plantation in Labuh Silan, Midai Island, Indonesia. ${ }^{39}$

Sheikh Ibrahim al-Hadhrami or Ibrahim Asmarqandi, besides Raden Ahmad Rahmatullah, also had a son, namely Ali Murtadho. Ali Murtadho lived in Champa and then migrated to Krishik (Kerisik), Pattani, until his death. His grave is among the old tombs in Kampong Parit al-Marhum, Pattani. According to another source, it was declared that his grave had been transferred to the Kelantan family tomb (Kampong Langgar). Shaikh Ibrahim al-Hadhrami in the Pattani cleric's version was Sheikh Ibrahim al-Ghazi in the recorded version of Cam people in Cambodia or Sayyid Ibrahim Asmarakandhi or as-Samarqandi in the Javanese clerical notes. Considering Sheikh Ibrahim al-Hadhrami had several names: Ibrahim al-Ghazi, Ibrahim Asmarakandhi or as-Samarqandi, Ibrahim Zainul Akbar, Zainuddin al-Akbar Ibrahim bin Jamaluddin al-Husein and Sunan Nggesik. ${ }^{40}$

\section{THE RELIGIOUS ROLE OF SHEIKH IBRAHIM AL- HADRAMI AND HIS DESCENDANTS IN THE SPREADING OF ISLAMIC DA'WAH IN JAVA}

Sheikh Ibrahim al-Hadhrami and his descendants played an essential role in spreading Islam in the archipelago through Campa, Pattani, and Java's land. The presence of Sheikh Ibrahim al-Hadhrami or Sheikh Ibrahim Asmarakandi in the land of Java was also a marker in setting the polite and friendly Islamic teachings. Thus, it could bring good characteristics and moderate religious features. It could not be separated from da'wah's strategy or systematic cultural strategy. It was mainly in the Javanese and Nusantara culture, which was very

${ }^{39}$ Abdullah, "Penyebaran Islam Dan Silsilah Ulama Sejagat Dunia Melayu"; Sunyoto, Atlas Wali Songo, Pustaaka IIman \& Lesbuni PBNU, 2017: Atlas Wali Songo.

${ }^{40}$ Abdullah, "Penyebaran Islam Dan Silsilah Ulama Sejagat Dunia Melayu"; Dewi Evi Anita, "Walisongo: Mengislamkan Tanah Jawa (Suatu Kajian Pustaka)," Wahana Akademika: Jurnal Studi Islam Dan Sosial 1, no. 2 (2016): 243-66. 
old, solid, and generally established. ${ }^{41}$ Sheikh Ibrahim al-Hadhrami had a wise method of introducing Islam, not instantly yet touching at all ages and walks. In da'wah, a strategy used by Sheikh Ibrahim al-Hadhrami was then applied in the world of pesantren, the kyai, ajengan, or the master teacher of religion in various forms. In the world of pesantren, applied fiqh al-ahkam to recognize and apply Islamic norms strictly and sincerely to become devout and consequent Muslims. However, when entering the community, fiqh al-da' wah was applied, where the teaching of religion was applied flexibly according to society's condition and education level. Moreover, the highest was figh al-hikmah. It was where all circles could accept the teachings of Islam, not only among the laity but also the nobility. It also could be accepted by Hindu and Buddhist clergy and other beliefs. ${ }^{42}$

The ability of Sheikh Ibrahim al-Hadhrami to raise the beliefs of the Ummah through a tireless quest of da'wah accompanied by a high appreciation of the old religions of Hinduism, Buddhism, Tantrayana, Kapitayan, and others, as well as his maturity in managing the culture made the invitation in Islam accepted by almost all the population of the archipelago, especially in Java. Sheikh Ibrahim al-Hadhrami and the spreading proponents of Islam in the archipelago began with some strategic steps. First, tadrij (stages), i.e., did not impose religious teachings suddenly, so that necessary adjustment process. It was not infrequently born at the beginning of preaching. Society was still allowed to run old traditions such as drinking palm wine, eating pork, or trusting Danyang and Sanghyang. However, gradually, the behavior is straightened out. Second, 'adam al-haraj (not hurt). In bringing and introducing Islam, Sheikh Ibrahim al-Hadhrami did not harass the traditions of the local people, even the old religions and beliefs but strengthening them in an Islamic way. Sheikh Ibrahim al-Hadhrami understands that the archipelago is a multi-ethnic, multicultural, multilingual society, so diversity is part of sunnatullah. This grate should be grateful to be preserved and developed. With the strategy of da'wa, Sheikh Ibrahim al-Hadhrami had a role in introducing polite

${ }^{41}$ Arik Dwijayanto, "PRIBUMISASI ISLAM NUSANTARA: ANTARA NALAR BERAGAMA DAN GERAKAN SOSIAL KEAGAMAAN DI INDONESIA," QALAMUNA: Jurnal Pendidikan, Sosial, Dan Agama 9, no. 02 (2017): 71-92.

${ }^{42}$ Said Aqiel Siradj, "Tasawuf Sebagai Basis Tasamuh," Al-Tahrir: Jurnal Pemikiran Islam 13, no. 1 (2013): 87-106; Sunyoto, Atlas Wali Songo, Pustaaka IIman \& Lesbuni PBNU, 2017: Atlas Wali Songo. 
and friendly Islamic teachings (wasathiyah). Based on the value of tawassuth (moderate), tawazun (balanced) and tasamuh (tolerant), the principle of the middle way is called in the language of the Qur'an as ummatan wasathan (moderate society). ${ }^{43}$ The form of such a society by the Qur'an is called khair al-ummah (the best of society). Based on those bases, Sheikh Ibrahim al-Hadhrami and his descendants developed Islam in the archipelago, including Java. ${ }^{44}$

In Javanese historiography (Babad Tanah Jawi), it was stated that Sheikh Ibrahim al-Hadhrami or al-Samarkandi with his two sons, Raden Rahmat and Raden Ali Murtadlo, played an important role. They preached from Champa to Java around $1440 \mathrm{AD}$ as a milestone of the Islamic da'wa process. It was done in an organized and systematic. The missionary journey of Sheikh Ibrahim al-Hadhrami with his son became the center of the Islamization effort in Java and various places in the archipelago.$^{45}$ Raden Rahmat and Raden Ali Murtadlo, the sons of Sheikh Ibrahim al-Hadhrami, made the da'wa of Islam a significant flow in the change of Javanese society. Historical facts showed that through the da'wa of the two sons of Sheikh Ibrahim al-Hadhrami, the Islamic religion began to be widely embraced by the native elite in the family of the Majapahit king. He was also further embraced by the indigenous people widely. Raden Rahmat was later appointed Imam Masjid in Surabaya and known as Sunan Ampel. In contrast, his elder brother Raden Ali Murtadlo was appointed King of Pandita in Gresik and Sunan Gresik. ${ }^{46}$

It was undeniable that the development of Islamic preaching in Java was inseparable from the influence of Sheikh Ibrahim al-Hadhrami. It was then followed by his two sons, Raden Rahmat (Sunan Ampel) and Raden Ali Murtadlo (Sunan Gresik). The Islamic propagation centers

${ }^{43}$ Amir Maliki Abitolkha, Muhamad Basyrul Muvid, and Maulana Arafat Lubis, "Revitalizing National Political Values Through The Socio-Political Movements Of The Tarekat: Studied At The Political Social Role Of Tarekat Qadiriyah Wa Naqsyabandiyah In Nusantara," Al-Tahrir: Jurnal Pemikiran Islam 20, no. 2 (2020): 373-98.

${ }^{44}$ Sunyoto, Atlas Wali Songo, Pustaaka IIman \& Lesbuni PBNU, 2017: Atlas Wali Songo; Siradj, "Tasawuf Sebagai Basis Tasamuh."

${ }^{45}$ Ras, "The Genesis of the Babad Tanah Jawi: Origin and Function of the Javanese Court Chronicle"; Ricklefs, "The Evolution of Babad Tanah Jawi Texts: In Response to Day."

${ }^{46}$ Sunyoto, Atlas Wali Songo, Pustaaka IIman \& Lesbuni PBNU, 2017: Atlas Wali Songo. 
built by Sunan Ampel and Sunan Gresik were further developed by the sons and daughters, students, and even the grandchildren of the two brothers. Along the northern coast of Java, for example, in addition to Ampeldenta, where Raden Rahmat preached, there were da'wa centers in the west. It was the Giri Kedaton, the center of da'wa Raden Paku (Sunan Giri) that was the disciple and son-in-law of Sunan Ampel. To the west of Giri Kedaton, Islamic preaching centers were located in the Drajat area where Raden Qasim residence (Sunan Drajat) was the son of Sunan Ampel. To the west of Drajat, an Islamic propagation center called Sendang Duwur where the residence of Raden Nur Rahmat, son of Abdul Qohar bin Sheikh Abdul Malik alBaghdady, counted the nephew of Sheikh Datuk Abdul Jalil (Sheikh Siti Jenar). To the west of Sendang Duwur, an Islamic preaching center called Tuban where Raden Makhdum Ibrahim (Sunan Bonang) resided, son of Sunan Ampel. In the west of Tuban, there were Islamic propagation centers in Lasem residence Nyai Ageng Maloka, Sunan Ampel. She married Prince Wiranagara (Adipati Lasem), a student of Sunan Ampel. To the west of Lasem, there is an Islamic preaching center called Demak Bintara, where Raden Patah's residence, student, and son-in-law of Sunan Ampel. To the west of Demak Bintara, there are Islamic propagation centers called Kalijaga and Cirebon where dakwah and the residence of Raden Sahid (Sunan Kalijaga) and Syarif Hidayatullah (Sunan Gunung Jati), both students of Sunan Ampel. Even from the centers of da'wa, then developed centers of da'wa outside Java. ${ }^{47}$

\section{CONCLUSION}

Sheikh Ibrahim al-Hadhrami's role in spreading Islam in the archipelago is particularly in Pattani and Java. Sheikh Ibrahim al-Hadhrami in Pattani and Java introduced a polite and friendly Islamic teaching with moderate religious characteristics. His descendant developed the struggle of da'wah Sheikh Ibrahim al-Hadhrami in Pattani and Java.

${ }^{47}$ Fox, "Nine Saints of Java"; Kasdi, "The Role of Walisongo in Developing the Islam Nusantara Civilization"; M Mas' udi, "Genealogi Walisongo: Humanisasi Strategi Dakwah Sunan Kudus," Addin 8, no. 2 (2014): 53136; Sunyoto, Atlas Wali Songo, Pustaaka IIman \& Lesbuni PBNU, 2017: Atlas Wali Songo; Dony Darma Sagita, Mutiara Felicita Amsal, and Shafna Utami Nur Fairuz, "Analysis of Family Resilience: The Effects of the COVID-19," Sawwa: Jurnal Studi Gender 15, no. 2 (2020): 275-94. 
Later, it became a massive milestone of the Islamic da'wa process in an organized and systematic way. The da'wah journey of Sheikh Ibrahim al-Hadhrami with his descendant became the center of the Islamization effort in Pattani and Java, which grew Islamic da'wah centers in the archipelago.

\section{REFERENCES}

Abdullah, Haji Wan Mohd Shaghir. "Penyebaran Islam Dan Silsilah Ulama Sejagat Dunia Melayu.” Khazanah Fathaniyah, 1999.

Abdullah, W M Shaghir. Tarikh Fathani. Kuala Lumpur: Khazanah Fathaniyah, 1998.

. "Wawasan Pemikiran Islam Ulama Asia Tenggara, Jil.

1." Kuala Lumpur: Persatuan Pengkajian Khazanah Klasik Nusantara \& Khazanah Fathaniyah, 2000.

Abitolkha, Amir Maliki, Muhamad Basyrul Muvid, and Maulana Arafat Lubis. "Revitalizing National Political Values Through The Socio-Political Movements Of The Tarekat: Studied At The Political Social Role Of Tarekat Qadiriyah Wa Naqsyabandiyah In Nusantara." Al-Tahrir: Jurnal Pemikiran Islam 20, no. 2 (2020): 373-98.

Al-Sufri, Mohd Jamil. Tarsilah Brunei: The Early History of Brunei up to $1432 A D$. Vol. 1. Brunei History Centre, Ministry of Culture, Youth and Sports, 2000.

Al-Attas, Syed Muhammad Naquib. Historical Fact and Fiction. Penerbit UTM Press, 2011.

Algadri, Hamid. Dutch Policy against Islam and Indonesians of Arab Descent in Indonesia. Lp3es, 1994.

Anita, Dewi Evi. "Walisongo: Mengislamkan Tanah Jawa (Suatu Kajian Pustaka)." Wahana Akademika: Jurnal Studi Islam Dan Sosial 1, no. 2 (2016): 243-66.

Ardi, Mohammad Noviani, and Fatimah Abdullah. "The History of Islam in the Malay Archipelago: An Analytical Study of Abdullah Bin Nuh's Works," 2018. 
Boontharm, Dinar. "The Sultanate of Banten AD 1750-1808: A Social and Cultural History." University of Hull, 2003.

Bradley, Francis R. "Moral Order in a Time of Damnation: The Hikayat Pattani in Historical Context." Journal of Southeast Asian Studies 40, no. 2 (2009): 267-93.

Bruinessen, Martin Van. "Studies of Sufism and the Sufi Orders in Indonesia." Die Welt Des Islams 38, no. 2 (1998): 192-219.

Daud, Hasanudin. "Syeikh Ahmad Bin Muhammad Zain Al-Pattani: Peranan Dan Sumbangannya Dalam Perkembangan Ilmu Keagamaan/Hasanudin Bin Daud.” University of Malaya, 2003.

Dwijayanto, Arik. "Pribumisasi Islam Nusantara: Antara Nalar Beragama dan Gerakan Sosial Keagamaan di Indonesia." QALAMUNA: Jurnal Pendidikan, Sosial, Dan Agama 9, no. 02 (2017): 71-92.

Dwijayanto, Arik, and Yusmicha Ulya Afif. "A Religious State (A Study of Hasyim Asyari and Muhammad Iqbal's Thought on the Relation of Religion, State and Nationalism).” JUSPI (Jurnal Sejarah Peradaban Islam) 3, no. 2 (2020): 226-35.

Fox, James J. "Nine Saints of Java.” JSTOR, 2001.

Guillot, Claude, Hasan Muarif Ambary, and Jacques Dumarçay. The Sultanate of Banten. Gramedia Book Pub. Division, 1990.

Hall, D G E. "Problems of Indonesian Historiography." Pacific Affairs 38, no. 3/4 (1965): 353-59.

Handoko, Putut. "A Historical of Sunan Ampel (Raden Rahmad) and Sunan Boto Putih (Lanang Dhangiran) Surabaya." Voicing Peace” Harmony Through Multidisiplinary Study", 2017, 1-5.

Hayimasae, Numan. “Jaringan’Ulama Pattani Dengan Utara Semenanjung Tanah Melayu Abad Ke-18 Dan Ke-19.” Malaysia Dari Segi Sejarah, Bil. 37, 2009, Ms. 18-30., 2009.

Idris, Ghafirah. "Shaykh Zayn Al-Abidin Bin Muhammad AlFatanis Discourse on Eschatology." Kuala Lumpur: Kulliyah of Islamic Revealed Knowledge and Human Science ..., 2012. 
Johns, Anthony H. "The Role of Structural Organisation and Myth in Javanese Historiography." The Journal of Asian Studies 24, no. 1 (1964): 91-99.

Kasdi, Abdurrohman. "The Role of Walisongo in Developing the Islam Nusantara Civilization.” Addin 11, no. 1 (2017): 1-26.

Mas' udi, M. "Genealogi Walisongo: Humanisasi Strategi Dakwah Sunan Kudus." Addin 8, no. 2 (2014): 53136.

Mustapha, Ahmad Sharifuddin, Abdul Karim Ali, Nur Zainatul Nadra Zainol, and Intan Farhana Saparudin. "Islamic Scholars in Malay Archipelago: Sheikh Daud Al-Fatani (17691847M) Contribution's in Fiqh Al-Shafie." Journal of Social Transformation and Regional Development 2, no. 3 (2020): 92-100.

Nizam, Mohd Khairul, Mahmud Ahmad, and Nurul Jannah. "Syeikh Abdul Qadir Bin Abdur Rahim Al-Fathani Bukit Bayas (1864) Towards Hadith Works and Writings of Fiqh Muamalat A1Maliyyah: An Introduction of The Malay Jawi Manuscript Entitled: Risalah Fi Bayani Hukmi Bai'i War Riba.' International Journal of Nusantara Islam 2, no. 1 (2014): 32-41.

Purwanto, Bambang, and M Nursam. Gagalnya Historiografi Indonesiasentris. Ombak, 2006.

Raffles, Thomas Stamford. The History of Java: Volume I. Vol. 1. BoD-Books on Demand, 2018.

Ras, Johannes Jacobus. "The Genesis of the Babad Tanah Jawi: Origin and Function of the Javanese Court Chronicle." Bijdragen Tot de Taal-, Land-En Volkenkunde, no. 2/3de Afl (1987): 343-56.

Ricklefs, M C. "The Evolution of Babad Tanah Jawi Texts: In Response to Day." Bijdragen Tot de Taal-, Land-En Volkenkunde, no. 4de Afl (1979): 443-54.

Rinkes, Douwe Adolf. Nine Saints of Java. Malaysian Sociological Research Institute, 1996.

Sagita, Dony Darma, Mutiara Felicita Amsal, and Shafna Utami Nur Fairuz. "Analysis of Family Resilience: The Effects of the 
COVID-19." Sawwa: Jurnal Studi Gender 15, no. 2 (2020): 275-94.

Serjeant, Robert Bertram. The Sayyids of Hadramawt. School of Oriental and African Studies, University of London, 1957.

Shaghir'Abdullah, Wan Mohd. "Manhalush Shafi Syekh Daud AlFathani.” Kuala Lumpur: Khazanah Fathaniyah, 1992.

Shaghir Abdullah, Wan Mohd. "Syeikh Ahmad Al-Fathani: Pemikir Agung Melayu Dan Islam.” Persatuan Pengkajian Khazanah Klasik Nusantara; Khazanah Fathaniyah, 2005.

Siradj, Said Aqiel. "Tasawuf Sebagai Basis Tasamuh." Al-Tahrir: Jurnal Pemikiran Islam 13, no. 1 (2013): 87-106.

Sunyoto, Agus. Atlas Wali Songo, Pustaaka IIman \& Lesbuni PBNU, 2017: Atlas Wali Songo. Vol. 1. Buku Digital, 2017.

Teeuw, Andries, and David K Wyatt. "Hikayat Pattani." In Hikayat Pattani the Story of Pattani, 68-145. Springer, 1970. 